\title{
Correction to: A Study on Otorhinolaryngological Presentations in Covid 19 Patients in a Tertiary Health Care Center
}

\author{
S. G. Smitha ${ }^{1} \cdot$ Nikitha Pillai $^{1} \cdot$ Bindya Nayak $^{1}$ (D) Jedhin Raveendran $^{1}$
}

Published online: 27 September 2021

(C) Association of Otolaryngologists of India 2021

\section{Correction to: Indian J Otolaryngol Head Neck Surg https://doi.org/10.1007/s12070-021-02564-2}

The article [A Study on Otorhinolaryngological Presentations in Covid 19 Patients in a Tertiary Health Care Center], written by [S. G. Smitha, Nikitha Pillai, Bindya Nayak, Jedhin Raveendran], was originally published online on [27 April 2021] with Open Access under a [This article is licensed under a Creative Commons Attribution 4.0 International License, which permits use, sharing, adaptation, distribution and reproduction in any medium or format, as long as you give appropriate credit to the original author(s) and the source, provide a link to the Creative Commons licence, and indicate if changes were made. The images or other third party material in this article are included in the article's Creative Commons licence, unless indicated otherwise in a credit line to the material. If material is not included in the article's Creative Commons licence and your intended use is not permitted by statutory regulation or exceeds the permitted use, you will need to obtain permission directly from the copyright holder. To view a copy of this licence, visit http://creativecommons. org/licenses/by/4.0/]. With the authors' decision to cancel Open Access the copyright of the article changed on [02 June 2021] to (C) Association of Otolaryngologists of India 2021 with all rights reserved.

Publisher's Note Springer Nature remains neutral with regard to jurisdictional claims in published maps and institutional affiliations.

The original article can be found online at https://doi.org/10.1007/s12070-021-02564-2.

Bindya Nayak

bindya22@mail.com

S. G. Smitha

smitha_praveen@hotmail.com

Nikitha Pillai

pillai_nikitha@hotmail.com

Jedhin Raveendran

jedhinraveendran.k@gmail.com

1 Department of ENT, Kims Hospital, Bangalore, Karnataka, India 